\section{Xavier Labor Relations Institute -Xavier School of Management}

\author{
C. H. Area (East), Jamshedpur, Jharkhand 831001, India.
}

Tel: $\quad$ (91) 6573983329,3330

Email: $\quad$ admis@xlri.ac.in

Website: www.xlri.ac.in

XLRI - Xavier School of Management is a management school founded in 1949 by the Society of Jesus and based in Jamshedpur, Jharkhand, India.

\section{Fellow Programme in Management (FPM) at Xavier Labor Relations Institute}

Purpose: The programme aims to train prospective scholars to become highly skilled and innovative researchers and teachers in various aspects of management. It primarily aims at preparing students for careers as faculty members at premier academic institutions and for position outside academics requiring advanced research and analytical capabilities Eligibility: Citizens of India

Study Establishment: Fellowship is available for pursuing full-time, residential doctoral programme

Country of Study: India

Application Procedure: See the website

Additional Information: For more details please see the website scholarship-positions.com/fellow-programme-inmanagement-fpm-at-xlri-in-india/2017/08/17/

\section{For further information contact:}

Email: satellitecoord@xlri.ac.in

\section{Xerox Foundation}

6th Floor/PO Box 4505, 45 Glover Avenue, Norwalk, CT 06856-4505, United States of America.

Tel

(1) 8002759376

Email: $\quad$ D.Garvin.Byrd@xerox.com

Website: www.xerox.com

Contact: Dr Joseph M. Cahalan

Xerox Foundation is a US\$15.7 billion technology and services enterprise that helps businesses deploy Smarter Document Management strategies and find better ways to work. Its intent is to constantly lead with innovative technologies, products and services that customers can depend upon to improve business results.

\section{Xerox Technical Minority Scholarship}

Purpose: To provide funding to minority students enroled in one of the technical sciences or engineering disciplines

Eligibility: Open to citizens of the United States or visaholding permanent residents of African American, Asian, Pacific Island, Native American, Native Alaskan or Hispanic descent. Applicants must have grade point average of 3.0 or better

Level of Study: Postgraduate

Type: Scholarship

Value: Scholarships amount vary from US\$1,000US\$10,000

Frequency: Annual

Country of Study: United States of America 
Application Procedure: Applicants must submit the completed application form along with a curriculum vitae Closing Date: 30 September

Additional Information: worldscholarshipforum.com/ xerox-technical-minority-scholarship/

\section{For further information contact:}

Xerox Technical Minority Scholarship Programme office

Email: xtmsp@rballiance.com 